\title{
Mistä kehittävät työntutkimukset on tehty?
}

\author{
Engeström Yrjö, 1995: Kehittävä työntutkimus, Perusteita, tuloksia ja haasteita, Pai- \\ natuskeskus, Helsinki, Hallinnon kehittämiskeskus. Painatuskeskus, Helsinki.
}

Y

rjö Engeström on kirjoittanut kehittävästä työntutkimuksesta uuden lähestymistapaa kokoavan kirjan, jota monet aikuiskasvatuksen alueella toimivat tutkijat ja kehittäjät ovat varmasti jo pitkään odottaneet.

Kehittävän työntutkimuksen lähestymistapaa noudattavia erillisiä tutkimusraportteja on vuosien saatossa kertynyt melkoinen määrä, mutta itse lähestymistavan perusteita ja käytännön kehittämishankkeita yhdessä arvioivaa kirjaa ei tähän mennessä ole ollut olemassa. Engeström torjuu kirjan esipuheessa odotukset uudesta käsikirjasta, jossa esitettäisiin 'virallinen' ja 'oikeaoppinen' kaava ja tekniikat kehittävälle työntutkimukselle.

Engeström torjuu myös ajattelutavan, jonka mukaan kehittävää työntutkimusta tekevät tutkijat ajattelisivat ja työskentelisivät samalla tavalla. Engeström pyrkii avaamaan kehittävää työntutkimusta koulukuntaisesta kehittämisotteesta tutkimusotteeksi, joka on 'julkisen keskustelun ja kehittelyn alainen eikä valmis paketti' (7). Kirjan tekstiä leimaakin kehittävää työntutkimusta arvioiva ote, joka Poikkeaa aikaisemmasta kehittävän työntutkimuksen julkisuuskäytännöstä. Engeström nostaa nyt julkiseen keskusteluun myös asioita, jotka aiemmin jäivät sisäisen tutkijaverkoston 'tuotekehittelyn' ja 'laatukontrollin' varaan. Ehkä suhtautuminen myös 'ulkopuoliseen' kehittävän työntutkimuksen arviointiin muuttuu keskustelevampaan suuntaan.

Kirjassa haetaan uudella tavalla myös yhteyksiä tutkimussuuntauksiin, jotka ovat kehittävän työntutkimuksen tapaan yhdistäneet samaan analyysiin yksilön ja yhteiskunnan. Vaikka Engeströmin uusin kirja ei varsinaisesti tarjoa uutta tulkintaa kehittävästä työntutkimuksesta, toimii se hyvänä lähestymistapaa kokoavana perusteoksena, joka antaa riittävässä määrin myös suuntaviivoja kehittävän työntutkimuksen tulevaisuuden haasteille.

$\mathrm{E}$ ngeströmin kirja on muodoltaan eräänlainen kehityskertomus. Kertomuksesta syntyy menestystarina, jonka aikana kehittävä työntutkimus on muuntunut ammatillisen aikuiskoulutuksen kehittämisotteesta akateemisesti noteeratuksi tutkimusotteeksi. Kehityskertomus on luonteeltaan seuraavanlainen: Engeström käsittelee ensin kehittävän työntutkimuksen historiallisia juuria ja tutkijoiden motiivitaustaa. Kehittävän työntutkimuksen syntyvaiheista edetään teoreettiseen taustoittamiseen, jonka aikana käydään peräjälkeen läpi työn sosiologinen, työn psykologinen, kokemus-oppimisen ja toimintatutkimuksen lähestymistavat, jotka selkeimmin ovat vaikuttaneet kehittävän työntutkimuksen muotoutumiseen. Teoriakierroksen jälkeen Engeström esittelee tarkemmin neljä kehittävän työntutkimuksen hanketta. Hanke-esittelyn tarkoituksena on osoittaa, miten kehittävää työ tutkimusta on sovellettu käytännössä. Lopuksi kehityskertomus päättyy kehittävän työntutkimuksen tulevaisuuden haasteisiin.

$\mathrm{K}$ ehittävä työntutkimuksen syntyhistoria liittyy 1970-luvun opiskelijaliikkeeseen, jo yleispoliittisen toiminnan lisäksi pyrki luomaan edellytyksiä demokraattiselle ammattikäytännölle. Tulevat professioammattien haltijat pyrkivät vaikuttama ammattikäytäntöihin niin, että niissä olisi tilaa ihmisten kehittymiselle, yhteiskunnalliselle vaikutukselle ja työelämän käytäntöjen demokratisoinnille. Tulevat asiantuntija-ammattilaiset, kuten opettajat, lääkärit ja lakimiehet, halusivat vaikuttaa yhteiskunnalliseen kehitykseen analysoimalla työnsä yhteiskunnallisia seurausvaikutuksia.

Toinen tärkeä kehittävään työntutkimukseen vaikutteita antanut toimintakenttä oli työelämän aikuiskoulutus ja erityisesti henkilöstökoulutus. Tällä alueella oli tarvittavaa liikkuma-alaa ja sosiaalista tilausta kehittämistyölle, jonka avulla olisi mahdollista luoda edellytyksiä työn ja oppimisen sekä teorian ja käytännön elävälle liitolle. Eväitä tähän haasteeseen haettiin didaktisista teorioista, erityisesti kognitiivisista oppimisnäkemyksistä. Selkeimmin lähtökohtiin vaikutti Dauydovin (mm. 1988) oppimistoiminnan teoria, jonka pohjalta kehiteltiin $\mathrm{mm}$. orientaatioperustan käsitettä. Aikuiskoulutuksen ja didaktisten teorioiden pohjalta tutkijat muokkasivat itselleen työvälineitä, joiden varassa oli mahdollista sukeltaa vähitellen yhä syvemmälle työelämän käytäntöihin'. Samalla tutkijat etsivät didaktiikan keinoja ylittäviä työn erittelyn välineitä. Erilaisista teoreettisista aineksista luotiin vähitellen perustaa 'kehittävälle työntutkimukselle' koulukuntaisena kehittämisotteena, joka pyrki selvästi erottautumaan muusta toimintaorientoituneesta työelämän tutkimuksesta. kirjassaan toteaa, Toikka esitti 'voimakkaasti pelkistetyt ideaalityypit' työn historiallisesta muutoksesta, 
joiden varaan kehittävän työntutkimuksen tutkijat rakensivat omaa lähestymistapaansa. Sen mukaan historiallinen muutossuunta työelämässä johtaa yksilöllisestä ja kokemusperäisestä käsityöstä kollektiivisesti hallittuihin työprosesseihin. Toikan mallinnuksen ja kulttuurihistoriallisen toiminnan teorian eväiden avulla kehittävän työntutkimuksen tutkijat lähtivät analysoimaan työnkäytäntöjä ja tunnistamaan kehittyneemmän eli kollektiivisemman työn 'ituja'.

$\mathrm{E}$ ngeström kommentoi kirjassaan kriittisesti viime aikaista työelämän joustavuuskeskustelua, jonka mukaan tuotannossa ollaan siirtymässä massatuotannosta joustavan erikoistumisen strategioihin ja käsityön tuotantomenetelmiin' (25). Tämä joustavuuskeskustelu rikkoo sitä historiallisesta työn kehityksen logiikkaa, johon kehittävä työntutkimus on sitoutunut. Engeström torjuu tämän joustavuuskeskustelun kehitysnäkemyksen, mutta jättää viisaana miehenä oven auki myös tuleville kannan tarkistuksille. Vaikka Engeström kritikoi edellä kuvattua joustavuuskeskustelua sen yksinkertaistavasta luonteesta, pitää hän keskustelua kuitenkin kiinnostavana. Kehittävälle työntutkimukselle ominainen teoriakehitys näyttää etenevän erilaisten nelikenttä-ja kolmio-ja -syklimallien monimutkaistumisen avulla eteenpäin. On mielenkiintoista seurata, miten erilaisten mallien avulla tapahtuva teoriakehittely asteittain johtaa kehittävän työntutkimuksen omien lähtökohtien tarkistamiseen.

Kun Engeström etenee kirjassaan kehittävän työntutkimuksen teoreettiseen taustoittamiseen, käyttää hän työn sosiologisia, psykologisia, oppimisteoreettisia ja toimintatutkimuksellisia tutkimussuuntauksia ensisijaisesti kehittävän työntutkimuksen erottautumisjalustana. Positiivisena piirteenä tässä katsauksessa on se, että Engeström teoriaperinteiden terävän ja joskus liiankin kärjekkään kritikoinnin ohella myös kirjaa sen, mitä hänen mielestään muista teoriaperinteistä on opittavissa. Engeströmin esittämälle kritiikille on ominaista se, että hän niputtaa parilla lauseella yhteen arvostettuja tutkijoita ja antaa heistä suoraviivaisia arvioita. Ehkä se riittää hyvien, pahojen ja rumien luokitteluun. Osansa saavat niin 'suurten kertomusten' sosiologit kuin myös ihmisten 'hetkellisiä merkitysten muodostumisia' tutkivat keskusteluanalyytikot (71).

Engeström. kaipaa tutkimukseen konkreettisuutta ja samalla historiallista tarkastelua, jonka avulla hän haluaa löytää 'mikrotapahtumille' hetkellisyyden, satunnaisuuden ja yksilöllisyyden ylittävän historiallisesti etenevän logiikan. Tätä logiikkaa Engeström pyrkii löytämään organisaatioiden ja instituutioiden työprosesseista, jotka kehittävän työntutkimuksen tutkijat ovat valinneet analyysiyksiköikseen.

Kehittävä työntutkimus tuo täydentävän näkökulman teoreettiseen makro- ja mikrotarkasteluun ottamalla kohteekseen 'aikaan ja paikkaan sidotut konkreetit toimintajärjestelmät, organisaatiot ja instituutiot, jotka Engeströmin mukaan jäävät sivuun muissa hänen kuvaamissaan teoriatyypeissä (71). Engeströmin näkemyksen mukaan kehittävä työntutkimus pystyy lähestymistapaansa sisältyvän toiminnan käsitteen avulla sitomaan samaan tarkasteluun sekä yksilöt että rakenteet. Toiminnan yhteiskunnallis-institutionaalisen tulkinnan perusteella määrittyvät kehitystä eteenpäin vievät ristiriidat ja dilemmat, jotka voivat toimia ekspansiivisen oppimisen ponnahduslautoina työorganisaatioissa.

$\mathrm{E}$ ngeströmin kritiikin kärki (68) suuntautuu yksilöpsykologista toiminnan analyysiä kohtaan, johon 'sosiaaliset tekijät' liitetään vasta lopuksi ja joka jättää liian paljon tilaa mystiikalle ja yksilöiden toiminnan ennustamattomuudelle. Engeström korostaa Leontjevin (1977) toiminnan teorian mukaisesti toiminnan kohteellisuutta, kollektiivisuutta ja yhteisöllisyyttä. Yksilölliset teot ja niiden kohteet ovat osa kollektiivisen toiminta- järjestelmän kohdetta, mikä sanelee tavallaan toimijoille mahdollisen tekojen ja tavoitteiden horisontin (69). Engestömin tavoitteena on edistää kehittämistyötä, joka lähtee liikkeelle toimintajärjestelmän kollektiivisten motiivien ja tavoitteiden tutkimisesta ja jonka avulla tunnistetaan kehityksen 'ylärajat' eli maksimaaliset mahdollisuudet.

$\mathrm{T}$ eoriaosuus päättyy yhteen vetoon kehittävän työntutkimuksen toteutumisvaiheista, joka on erityisen kiinnostavaa luettavaa. Tähän yhteenvetoon Engeström on koonnut kokemuksia ja opetuksia kehittävän työntutkimuksen hankkeiden ongelmien etnografiasta, historiallisesta analyysista, toimintojen nykyisten ristiriitojen analyysista ja lähikehityksen vyöhykkeen kuvauksesta. Edelleen Engeström käy läpi kehittävän työntutkimuksen tutkimushankkeiden perusteella kokemuksia uuden toimintamallin suunnittelusta, käyttöönotosta, arvioinnista ja tuloksista sekä tulosten yleistettävyydestä.

Tarkemmin esiteltäviksi hankkeiksi Engeström on valinnut siivoustyön hallintatutkimusprojektin (Engeström \& Engeström 1984), joustavaan valmistusjärjestelmän eli FMS:n käyttöönottoon liittyvän tutkimuksen (Norros, Toikka \& Hyötyläinen 1988), Suomen Liikemiesten Kauppaopistossa toteutetun opetustyötä koskevan tutkimuksen (Miettinen 1993) sekä työsuojeluhallinnon työtä ja työpaikkatarkastuksia koskevan tutkimuksen (Virkkunen 1995). Engeström korostaa, että esiteltävät tutkimukset eivät ole malliesimerkkejä hankkeista, joissa on läpikäyty koko kehittävän työntutkimuksen syklimalli kehittävän toiminnan nykytilan ja historian tutkimisesta toiminnan nykytilan analyysiin ja kehitysristiriitojen tunnistamiseen ja edelleen uuden toimintamallin kehittelyyn, soveltamiseen ja arviointiin. Engeström ei pidä perusteluna näkemystä, jonka mu- 
kaan kehittävässä työntutkimuksessa olisi aina toteutettava koko kehityssykli, ennen kuin voidaan puhua onnistuneesta kehittävän työntutkimuksen hankkeesta. Hankkeet voivat keskittyä kehityssyklin eri vaiheisiin. Kuten Engeström tuo esille, on olemassa myös hankkeita, joissa koko sykli läpikäydään. Tällaiseksi hankkeeksi hän nimeää terveyskeskusten työkäytäntöjen kehittämiseen liittyneen LEVIKE-hankkeen, jota tässä kirjassa ei kuitenkaan tarkemmin esitellä.

$\mathrm{M}$ ielenkiintoisia ovat Engeströmin omat johto päätökset kehittävän työntutkimuksen eri hankkeiden saavutuksista ja ongelmista. Engeströmin mukaan näyttää siltä, että useissa hankkeissa on lähdetty kehittelemään uusia kognitiivisia työvälineitä ja toimintamalleja, mutta nämä kehitelmät ovat kompastuneet organisatorisyhteistoiminnallisiin ehtoihin. Useat kehittämishankkeet on katkaistu kesken, mikä on vaikeuttanut uusien toimintamallinen ja välineiden leviämisen seuraamista, dokumentointia ja teoreettista erittelyä. Kehittämistoiminnan sosiaalisten ja organisatoristen ehtojen tarkempi huomiointi ja erittely onkin Engeströmin mukaan kehittävän työntutkimuksen tärkeä haaste tulevaisuudessa. Toimintajärjestelmän sijasta tulisi Engeströmin mukaan tarkastelua laajentaa toiminta järjestelmien välisiin verkkoihin.

Toimintajärjestelmien välisten dialogisten suhteiden ja toimintajärjestelmien verkkojen tutkiminen pitää sisällään kuitenkin eritasoiset muutosprosessit yksilökehityksestä kollektiivisiin toimintajärjestelmiin, yhteiskuntien historialliseen muutokseen ja jopa inhimilliseen lajikehitykseen.

Engeström näyttää vain laajentavan tutkimusorientaatiotaan, mikä saattaa olla vastaus esitettyyn kritiikkiin. Esitetyn mukaan kehittävä työntutkimus päätyy tutkimuksissaan kapeaan työprosessikeskeisyyteen, organisaatioiden valta- ym. rakenteiden sivuuttamiseen ja yhteiskuntateoreettisten premissien heikkouteen (esiin Kasvio 1990, 140). Koko yhteiskunnan ja kulttuurin yleiset ristiriidat ja kehitysmahdollisuudet löytyvät Engeströmin mukaan jokaisesta erityisestä toimintajärjestelmästä ja toisiinsa kytkeytyvistä toimintajärjestelmien verkoista 'alhaalta päin' analysoimalla (234). Näissä analyyseissä kehittävällä työntutkimuksella on Engeströmin mielestä erityisesti paljon opittavaa tutkimusotteista, joissa on keskitytty mikrotason yhteistoiminnallisten käytäntöjen analysoimiseen organisatorisissa, kulttuurisissa ja yhteiskunnallisissa konteksteissa. Tällaisia ovat tutkimustraditiot, jotka antavat välineitä työssä ja organisaatiossa tapahtuvan puheen ja interaktion tarkkaan erittelyyn.

Kehittävän työntutkimuksen nykyinen tutkimusmetodologinen linja on saanut vaikutteita viime aikaisesta diskurssianalyyttisesta ja sosiaalista konstruktivismia koskevasta keskustelusta, Sen mukaan yhteiskunnallinen ja kulttuurinen todellisuus tuotetaan sosiaalisesti ja kielellisesti erilaisissa arkielämän käytännöissä ja instituutioissa. Intressit sekä johdon ja työntekijäryhmien väliset näkemysristiriidat kääntyvät kehittävässä työntutkimuksessa erilaisiksi tulkintakehyksiksi ja bahtinilaisittain (Bakhtin 1982) moniäänisyydeksi. Yhteiskuntatieteellinen rakennekieli puuttuu kokonaan. Intressiryhmien sijasta kehittävässä työntutkimuksessa tunnistetaan ääniä, puhelajeja ja toimintaa ohjaavia käsikirjoituksia. Kilpailevat käsikirjoitukset ovat analyyseissä hyvin kognitiivisia asioita. Käsikirjoitukset ovat muistiin varastoituneita kaavioita, joiden avulla ihminen hahmottaa tai ohjaa toimintaansa (65). Sosiaalinen, yhteiskunnallinen ja kulttuurinen ovat kehittävässä työntutkimuksessa lopulta hyvin kognitiivisia ja jopa biologisia ja ihmisen lajikehitykseen liittyviä asioita. Engeströmhän (1987) hahmottelee toimintajärjestelmän käsitteen ihmisten lajikehitystä analysoimalla. Lajikehityksestä siirrytään suoraan huimalla hypyllä organisaatiokonteksteihin.

$\mathrm{E}$ ngeströmin kirja osoittaa, että kehittävä työntutkimus on seurannut aikaansa ja pystynyt jatkuvasti uusiutumaan. Kuitenkin kehittävä työntutkimus on myös säilyttänyt 90-luvun tutkimusotteessaan vakaan käsityksen työn historiallisesta ja lainomaisesta kehityksestä. Postmodernin yhteiskunnan epävarmuuspuhe ei kosketa kehittävän työntutkimuksen tekijöitä. Heillä on selkeä historiallinen käsitys siitä, mikä on edistystä ja mikä taantumista. Heille maailma ja kehitys ovat hallittavissa. Tällainen usko tuntuu kadehdittavan auvoiselta. Kun käsityömäinen työ on menneisyyden työtyyppi, joka edustaa historiallista ja romanttista jäännettä kokonaisesta työstä, edustaa käsityö kehittävän työntutkimuksen lähestymistavassa taantumaa jopa tutkijan työssä. Engeström luottaa siihen, että tiimi- ja verkostorakenteilla tehdään tulevaisuudessa nopeammin ja helpommin tutkimusta. Näin varmaan onkin. olisiko kuitenkin syytä pysähtyä analysoimaan, onko tiimi- ja verkostoryhmissä tehtävä tutkimus myös parempaa tutkimusta ja mikä jää tavoittamatta, jos käsityömäinen ote jää pahasti jalkoihin.

\section{LÄHTEET}

Bakhtin, M.. M. 1982 : The dialogic imagination. Austin.. University of Texas Press.

Davydov, V. V. 1988: Problems of developmental teaching. Soviet Education, XXX (840).

Engeström Y., Engeström R.. 1984.. Siivoustyön hallinta. Helsinki: Servi Systems. 
Engeström Y. 1987: Learning by expanding: An activity-theorietical approach to developmental research Helsinki: Orienta-Konsultit.

Kasvio A.. 1990: Työorganisaatioiden tutkimus ja niiden tutkiva kehittäminen. Kirjallisuuskatsaus. Tampereen yliopisto. Työelämän tutkimuskeskus. Saira T4.

Leontiev A..N. 1977: Toiminta, tietoisuus, persoonallisuus. Helsinki: Kansankulttuuri.

Miettinen R.. 1993: Oppitunnista oppimistoimintaan. Tutkimus opetuksen ja opettajankoulutuksen kehittämisestä Suomen Liikemiesten Kauppaopistossa vuonna 1986-1991. Helsinki: Gaudeamus.

Norros L., Toikka K. \& Hyötyläinen R.. 1984: FMS:n käyttöönotto: Tapaustutkimuksen tuloksia. julkaisussa J. Ranta \& P. Huuhtanen (toim.) Informaatiotekniikka ja työympäristö Osa III Informaatiotekniikka metallituote- ja konepajateollisuudessa. Työsuojelurahaston julkaisuja A3.

Toikka K.. 1984: Kehittävä kvalifikaatiotutkimus. Valtion koulutuskeskuksen julkaisusarja B n:o 25.

Virkkunen J. 1995: Työpaikkatarkastuksen ristiriidat ja niiden ylittämisen mahdollisuudet. Tutkimus keskusteluun perustuvan työn välineistä ja tuloksellisuudesta. Työpoliittinen tutkimus. Nro 123. Työministerï̈. Helsinki 1995.

Karin Filander 